\title{
Implications of territory size for the measurement and prediction of salmonid abundance in streams ${ }^{1}$
}

\author{
J.W.A. Grant, S.ó. Steingrímsson, E.R. Keeley, and R.A. Cunjak
}

\begin{abstract}
Information about territory size is useful for both the measurement and prediction of salmonid abundance. Percent habitat saturation (PHS), the percentage of the stream area occupied by the territories of salmonid fishes, is a better measure of abundance than population density because the former integrates the effects of $(a)$ several age-classes or species in a stream, and $(b)$ variation in growth rate or sampling date. "Effective density" or "effective PHS," calculated by weighting crude density $\left(\right.$ no. $\cdot \mathrm{m}^{-2}$ ) or PHS by the number of organisms in the sampling unit, more accurately reflects density from the organism's point of view than does crude density or PHS. Effective density and PHS of Atlantic salmon (Salmo salar) in Catamaran Brook, New Brunswick, increased by 0.4 fish per $\mathrm{m}^{2}$ and $4 \%$, respectively, for each order of magnitude decrease in the area of the sampling unit. Literature data suggested that territory size is inversely related to food abundance and can be used to predict changes in salmonid abundance that accompany changes in food abundance. The allometry of territory size was a better predictor of the decline in density of a cohort of Atlantic salmon in Catamaran Brook than the allometry of metabolic requirements.
\end{abstract}

Résumé : L’information relative à la taille du territoire est utile tant pour la mesure que pour la prévision de l'abondance des salmonidés. Le pourcentage de saturation de l'habitat, soit le pourcentage de la superficie d'un cours d'eau qui est occupé par les territoires des salmonidés, est une meilleure mesure de l'abondance que la densité de la population parce qu'il intègre les effets $(a)$ de la multiplicité des classes d'âge ou des espèces dans le cours d'eau et (b) de la variation des taux de croissance ou des dates d'échantillonnage. La « densité effective » ou le «pourcentage effectif de saturation de l'habitat », calculés en pondérant la densité brute (nombre de poissons $\cdot \mathrm{m}^{-2}$ ) ou le pourcentage de saturation de l'habitat en fonction du nombre d'organismes dans l'unité d'échantillonnage, reflètent plus exactement la densité du point de vue de l'organisme que ne le fait la densité brute ou le pourcentage de saturation de l'habitat. La densité et le pourcentage de saturation de l'habitat effectifs dans le cas du saumon atlantique (Salmo salar) du ruisseau Catamaran, au Nouveau-Brunswick, se sont accrus de 0,4 poisson par $\mathrm{m}^{2}$ et de $4 \%$, respectivement, pour chaque diminution d'un ordre de grandeur dans la superficie de l'unité d'échantillonnage. Les données tirées de la documentation scientifique laissent entendre que la taille du territoire varie en raison inverse de l'abondance de la nourriture et peut être utilisée pour prévoir les changements dans l'abondance des salmonidés qui accompagnent les changements dans l'abondance de la nourriture. L'allométrie de la taille du territoire était un meilleur facteur de prévision de la baisse de la densité d'une cohorte de saumon atlantique dans le ruisseau Catamaran que l'allométrie des besoins métaboliques.

[Traduit par la Rédaction]

\section{Introduction}

The abundance of Atlantic salmon (Salmo salar) in fresh water can be usefully studied at any of the nine orders of magnitude of spatial scale that exist within watersheds (Imhof et al. 1996; Folt et al. 1998). For example, information on summer habitat use and preference are best gathered at the level of microhabitat or site (e.g., deGraaf and Bain
1986; Morantz et al. 1987), whereas winter habitat use is best studied at the level of reach or stream (Cunjak 1996). In contrast, action at a watershed level is required to restore salmonid populations in acid stressed environments (Lewis et al. 1996).

Studies of salmonids are most frequently conducted at the site level $\left(\sim 100 \mathrm{~m}^{2}\right.$, see Imhof et al. 1996), a spatial scale that is too small to address many ecological questions

Received December 3, 1997. Accepted October 29, 1998. J14329

J.W.A. Grant ${ }^{2}$ and S.Ó. Steingrímsson. Department of Biology, Concordia University, 1455 de Maisonneuve Blvd. West, Montréal, QC H3G 1M8, Canada.

E.R. Keeley. Department of Zoology, The University of British Columbia, 6270 University Blvd., Vancouver, BC V6T 1Z4, Canada.

R.A. Cunjak. Department of Biology and Faculty of Forestry and Environmental Management, University of New Brunswick, Bag Service 45111, Fredericton, NB E3B 6E1, Canada.

${ }^{1}$ Contribution No. 42 of The Catamaran Brook Habitat Research Project.

${ }^{2}$ Author to whom all correspondence should be addressed. e-mail: grant@ vax2.concordia.ca 
(Lewis et al. 1996; Armstrong et al. 1998). To rectify this situation, research is increasingly conducted at a variety of larger spatial scales (Cunjak 1996; Imhof et al. 1996; Lewis et al. 1996; Rabeni and Sowa 1996). While this trend is laudable, we believe that questions regarding the mechanisms of competition should often be considered at small spatial scales (see Ray and Hastings 1996).

In this paper, we deliberately take a small-scale approach to the measurement and prediction of the abundance of salmonid fishes in streams. Our basic unit of study is the territory of an individual fish. The study of territories may provide valuable information regarding the habitat, space, and food requirements of individuals with the highest status (sensu Gross 1996) in stream populations (Puckett and Dill 1985; Elliott 1990; Grant 1990). Because defended home ranges (i.e., territories) tend to be smaller than undefended home ranges (Grant et al. 1992), territory size potentially provides information about the minimum spatial requirements of individuals or the maximum density of populations. An allometric territory size relation (e.g., Grant and Kramer 1990; Keeley and Grant 1995) may allow this information to be scaled for individuals of any size in the population, or even among species.

The purpose of our paper is to explore how such a small-scale, space-use approach may provide new insights about the abundance of stream-dwelling salmonids. Specifically, we address how to measure abundance, how spatial scale affects those measurements, how food and (or) space affect abundance, and whether the concept of self-thinning is useful for predicting declines in the abundance of cohorts.

\section{How to measure the abundance of salmonids?}

The abundance of a population is usually expressed as population density, the number of organisms per unit area (Krebs 1989; Begon et al. 1996). There are at least two major problems, however, associated with using population density as a general measure of abundance. First, it is difficult to identify, much less count, individuals in modular organisms such as plants. Second, even in unitary organisms (sensu Begon et al. 1996), such as salmonid fishes, individuals within a population often vary in body size. Individuals differing in body size should not necessarily be treated equally in estimates of abundance.

Atlantic salmon are a classic example of a species with indeterminate growth. Juvenile salmon emerge from the gravel weighing about $0.15 \mathrm{~g}$ (Randall 1982), leave the stream as smolts weighing about $40 \mathrm{~g}$, and begin returning to the stream to spawn as grilse weighing about $1400 \mathrm{~g}$ (Scott and Scott 1988). Even in fresh water, there are usually at least three age-classes of juveniles present in Canadian streams, varying in body length by 6-fold and in body mass by 260-fold (Scott and Scott 1988).

How does one measure abundance for a population of juvenile Atlantic salmon when individuals vary so much in size? For studies of population dynamics, it is important to report population density separately for each age-class (e.g., Elliott 1984; Cunjak and Therrien 1996). But, because different age-classes or species of juvenile salmonids often compete for habitat and food (Symons and Heland 1978;
Fausch 1988), strong age-classes often affect the growth and mortality rates of other age-classes or species in the stream (Kennedy and Strange 1986). In some circumstances, therefore, it will be desirable to estimate the total abundance of all age-classes or species in the stream. Summing densities of different age-classes will not be adequate for studies of energy flow or production because a $25 \mathrm{~g}$ parr eats more food and occupies more space than a $0.2 \mathrm{~g}$ individual.

One can circumvent the problem of individuals differing greatly in size by summing biomass (e.g., g. $\mathrm{m}^{-2}$ ) rather than densities (Krebs 1994). Biomass is used routinely by forestry and fisheries biologists. The major drawback with using biomass is the assumption that two small fish are equivalent to one larger fish of the same mass. Two smaller fish eat more food than one larger fish of equivalent mass because of the allometry of food consumption $\left(M^{0.73}\right)$, where $M$ is body mass) and metabolic rate $\left(M^{0.87}\right)$ in salmonid fishes (for a review, see Steingrímsson and Grant 1999). To solve the allometric problem, one can sum the metabolic requirements (e.g., Bohlin et al. 1994) or the food consumption (e.g., Marschall and Crowder 1995) of cohorts in the population. The units of these "allometrically correct" measures, however, are less heuristically appealing than biomass per $\mathrm{m}^{2}$.

An alternative method for expressing abundance is to estimate the spatial requirements of a population. Some individuals defend feeding territories in virtually all populations of stream-dwelling salmonids (see Titus 1990, for a review). While many factors influence territory size, body size alone explains between 69 and $97 \%$ of the variation in territory size (Keeley and Grant 1995; Keeley and McPhail 1998). If territory size is a useful predictor of the space required by a salmonid fish, then we can use the allometric relationship to calculate habitat fullness. Percent habitat saturation (PHS) is the sum of the predicted territory areas of all salmonids in the stream (Grant and Kramer 1990). To calculate PHS, for $n$ cohorts, size classes or species of salmonids in a stream:

$$
\mathrm{PHS}=100 \cdot \sum_{i=1}^{n} D_{i} \cdot T_{i}
$$

where $D_{i}$ is the density (no. $\mathrm{m}^{-2}$ ) of size class $i$ and $T_{i}$ is the territory size $\left(\mathrm{m}^{2}\right)$ for size-class $i$ (predicted from: $\log _{10}$ territory size $=2.61 \log _{10}$ fork length $(\mathrm{cm})-2.83$; Grant and Kramer 1990). When calculating the PHS for Atlantic salmon in Catamaran Brook, we used the territory size regression specifically for that population: $\log _{10}$ territory size $=-3.23+3.91 \log _{10}$ fork length -0.76 age, where age is 0 for young-of-the-year fish or 1 for older fish (Keeley and Grant 1995). A PHS of 100 means that salmonid fishes fill the surface area of the stream bottom, assuming that territory size is a reasonable estimate of the space required by both territorial and non-territorial individuals. PHS is a convenient measure of salmonid abundance because it gives the fisheries manager an immediate idea of the likelihood that a population is at carrying capacity. In a comparative survey, density dependent population responses were likely when PHS exceeded 27\% (Grant and Kramer 1990), presumably because most habitat in a stream is unsuitable for juvenile salmonids. Ideally, one should calibrate the PHS that is 
equivalent to the carrying capacity for each population under study.

We suggest that PHS is a better measure of abundance than density, even when only one age-class is being studied. For example, Steingrímsson (1996; see also Steingrímsson and Grant 1999) counted, from behind a blind, the number of age $0+$ salmon in $80,1-\mathrm{m}^{2}$ quadrats of Catamaran Brook, New Brunswick over the 1995 growing season. The average density and PHS for $0+$ salmon were 2.2 per $\mathrm{m}^{2}$ and $16.7 \%$, respectively. While density declined from an average of 4.0 per $\mathrm{m}^{2}$ in late June to 0.7 per $\mathrm{m}^{2}$ in late August (Fig. $1 a ; r=$ $-0.95, n=9, P<0.01$ ), average PHS showed no marked seasonal trend (Fig. $1 b ; r=-0.04, n=9, P>0.05$ ). Hence, measuring only density would have given the false impression that abundance was declining seasonally in Catamaran Brook. In contrast, measuring PHS demonstrated that the decline in population density was just balanced by an increase in the spatial requirements of the surviving, larger individuals. PHS incorporates important variation due to sampling date, size of fish, or growth rates between years that is ignored if population density is used as an index of abundance.

\section{Spatial scale and population abundance}

At what spatial scale should population abundance be measured? Operationally, this question can be broadly framed as a problem of optimal "quadrat" size. Quadrat size is an important problem for ecologists only because of spatial heterogeneity in population abundance. If individuals are uniformly distributed in the habitat, then measures of population abundance at all spatial scales will give the same answer.

Optimal quadrat size can be defined either statistically or ecologically (Krebs 1989). The statistical definition is the easier of the two because of its narrower goal: the quadrat size that estimates population density with the greatest precision for a given sampling area, time, or money. High precision requires a low standard error of the mean - i.e., low variance in density between quadrats. Hence, it is often desirable to increase the spatial heterogeneity in density within a quadrat in order to decrease the variance of density between quadrats (Krebs 1989, pp. 64-72). In contrast, there is no single ecological definition of optimal quadrat size, because the optimum will depend upon the goal of the study (see Introduction). Because one of our goals is to evaluate the relative "fullness" of habitats, we will explore how spatial scale influences measures of population abundance.

The standard measure of population abundance for individuals of the same size is the number of organisms per area of habitat. This "crude density" (Smith 1996) is equivalent to the "resource-weighted density" of Lewontin and Levins (1989), when space is the resource. A fundamental problem with crude density is that not all habitat within the sampled area will be suitable for the organism. Hence, a better measure of population density would consider only suitable habitat. But, habitat cannot be dichotomized into completely suitable and completely unsuitable. Instead, habitat suitability will likely be continuously distributed and influenced by population density (Fretwell and Lucas 1970).
Fig. 1. (a) Density and (b) PHS of young-of-the-year Atlantic salmon counted in $80,1-\mathrm{m}^{2}$ quadrats of Catamaran Brook, during the summer of 1995 . Solid lines join the mean values for each of the nine counts. Densities of 0 are placed on the $\mathrm{x}$-axis.
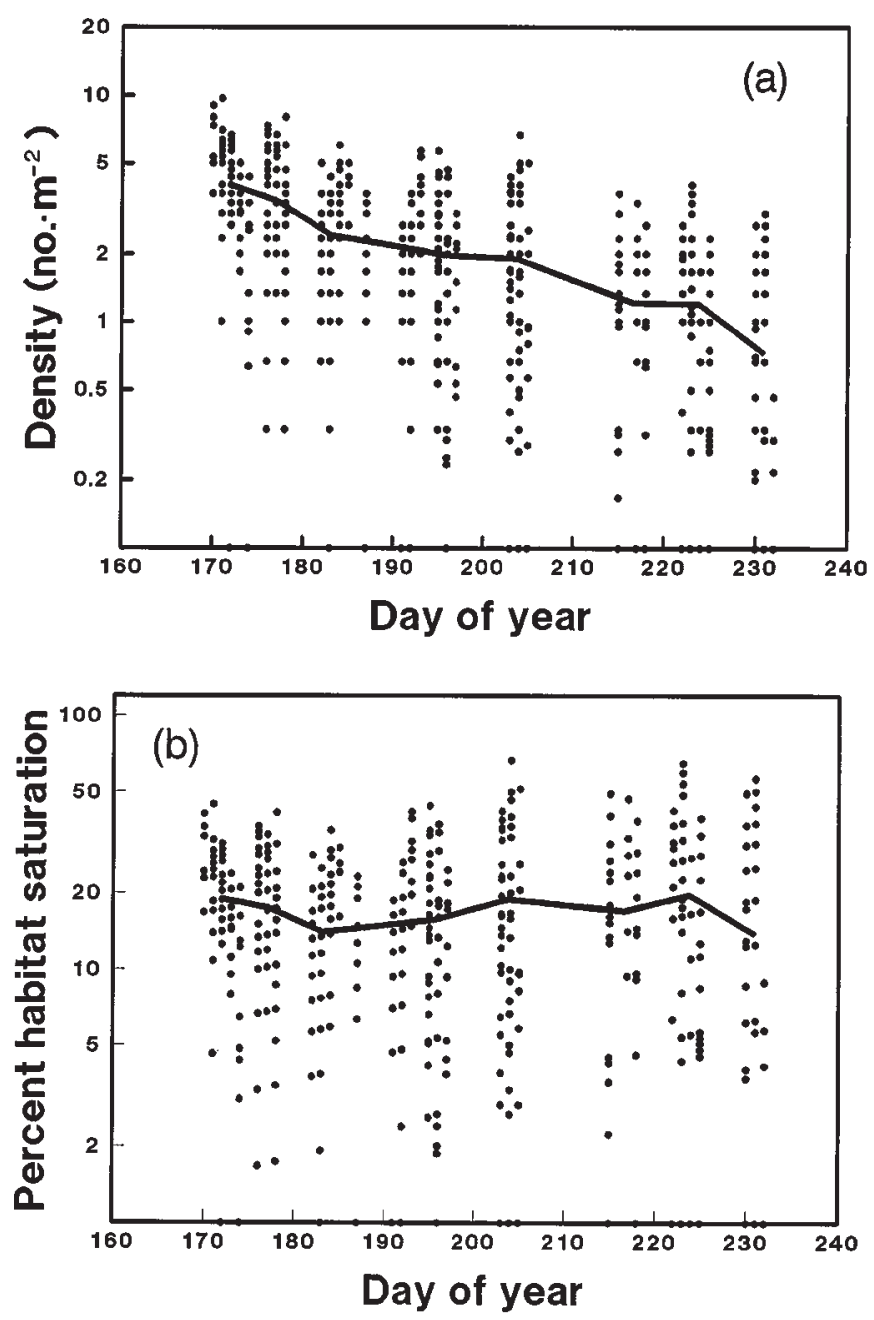

An alternative approach is to express the average density that the organisms in the population actually experience (see Folt et al. 1998). Such an "organism-weighted density" or "effective density" (Lewontin and Levins 1989) is calculated by weighting the crude densities for each sampling unit by the number of organisms in the unit. This weighting scheme is equivalent to using the crude density as a continuous measure of habitat suitability. Crude and effective density are analogous to average and typical group size in the behavioural ecological literature (Jarman 1974). To estimate the "effective density" of a population accurately, the heterogeneity in density within quadrats should be minimized (Lewontin and Levins 1989). Hence, the measure of effective density will continue to increase as quadrat size (i.e., spatial scale) decreases, until the heterogeneity within quadrats is zero. The smallest spatial scale possible is to measure the crude density surrounding each individual in the population. Because of the limitations in using crude density as a measure of salmonid abundance (see previous section), one can also calculate effective PHS: the PHS of a sampling unit weighted by the number of organisms in the unit. 
To illustrate the effects of spatial scale on measures of population abundance, we analyzed Steingrímsson's (1996) data for Catamaran Brook (Fig. 1). He counted 0+ salmon in "flat" habitats (sensu Cunjak et al. 1993) at seven sites for a total of $80,1-\mathrm{m}^{2}$ quadrats. Effective abundance can, therefore, be calculated at three different spatial scales from these data: quadrat $\left(1 \mathrm{~m}^{2}\right)$, site $\left(80 / 7=11.4 \mathrm{~m}^{2}\right)$, and habitat type $\left(80 \mathrm{~m}^{2}\right)$. At the largest spatial scale, effective density and PHS are identical to crude density and PHS, respectively. At the 1- and $11.4-\mathrm{m}^{2}$ scales, effective density and PHS are the weighted average crude density and PHS for 80 and 7 sampling units, respectively. As spatial scale increased from 1 to $80 \mathrm{~m}^{2}$, the average estimate of effective population density over the nine time periods decreased by $28 \%$, from 2.9 to 2.1 per $\mathrm{m}^{2}$ (Fig. 2a), whereas average effective PHS decreased by $32 \%$, from 24.5 to $16.7 \%$ (Fig. $2 b$ ).

To determine whether the patterns observed in Steingrímsson's data also occur at larger spatial scales, we analyzed the electrofishing data for Catamaran Brook from 1991 to 1996 (R.A. Cunjak, unpublished data). Effective abundance can be calculated for each year at four spatial scales (Cunjak et al. 1993): site $\left(n=20\right.$, mean area $\left.=106 \mathrm{~m}^{2}\right)$, habitat type (i.e., flats, runs, riffles and pools) within reaches $(n=10$, mean area $\left.=206 \mathrm{~m}^{2}\right)$, reach $\left(n=3\right.$, mean area $\left.=780 \mathrm{~m}^{2}\right)$, and the total area sampled (mean area $=2337 \mathrm{~m}^{2}$ ), approximately $2.2 \%$ of the stream area. As spatial scale increased from 106 to $2337 \mathrm{~m}^{2}$, the average effective population density decreased by $34 \%$ from 1.50 to 0.99 salmon per $\mathrm{m}^{2}$, whereas the average effective PHS decreased by $26.2 \%$ from 21.4 to $15.8 \%$ (Fig. 3). To quantify these relationships, we calculated least-square regressions for each year and then the average slope and intercept of these six regressions: effective population density $\left(\right.$ no. $\cdot \mathrm{m}^{-2} \pm 95 \% \mathrm{CL}$ ) $=2.24$ $( \pm 0.75)-0.367( \pm 0.185) \log _{10}$ area $\left(\mathrm{m}^{2}\right)$; effective PHS $(\% \pm 95 \%$ CL $)=30.1( \pm 7.4)-4.19( \pm 1.33) \log _{10}$ area $\left(\mathrm{m}^{2}\right)$. The slopes of the least-square regressions for Steingrímsson's data were very similar, and well within the 95\% CL for the electrofishing data (effective density = $2.91-0.413 \log _{10}$ area; effective PHS = $24.6-4.06 \log _{10}$ area). The similarity in the slopes from the two data sets suggests a consistent decline in effective salmonid abundance in Catamaran Brook over 3.5 orders of magnitude of spatial scale. For an increase in spatial scale of one order of magnitude, effective population density declines by about 0.4 fish per $\mathrm{m}^{2}$, whereas effective PHS declines by about $4 \%$.

We were not expecting the intercepts of the two data sets to be similar, because Steingrímsson sampled only one of four habitat types in one of three reaches in one of six years. Nevertheless, the apparent differences in the intercepts are interesting. Population density appeared to be higher in Steingrímsson's data than in the complete brook (compare open circles to solid circles in Fig. 3), whereas PHS showed the opposite trend (compare open triangles to solid triangles in Fig. 3). This apparently contradictory result occurred because Steingrímsson studied only flats, ideal habitat for age $0+$ salmon but not for age $1+$ or $2+$ parr. Flat habitats have high average densities but low average PHS.

Spatial scale can clearly have a large influence on our perception of population abundance (e.g., Fig. 3), even when crude abundance does not change. Because population
Fig. 2. (a) Effective density and (b) effective PHS from Fig. 1, calculated nine times over the summer at three different spatial scales: $80 \mathrm{~m}^{2}(\boldsymbol{O}), 11.4 \mathrm{~m}^{2}(\boldsymbol{\square})$, and $1 \mathrm{~m}^{2}(\boldsymbol{\Delta})$.
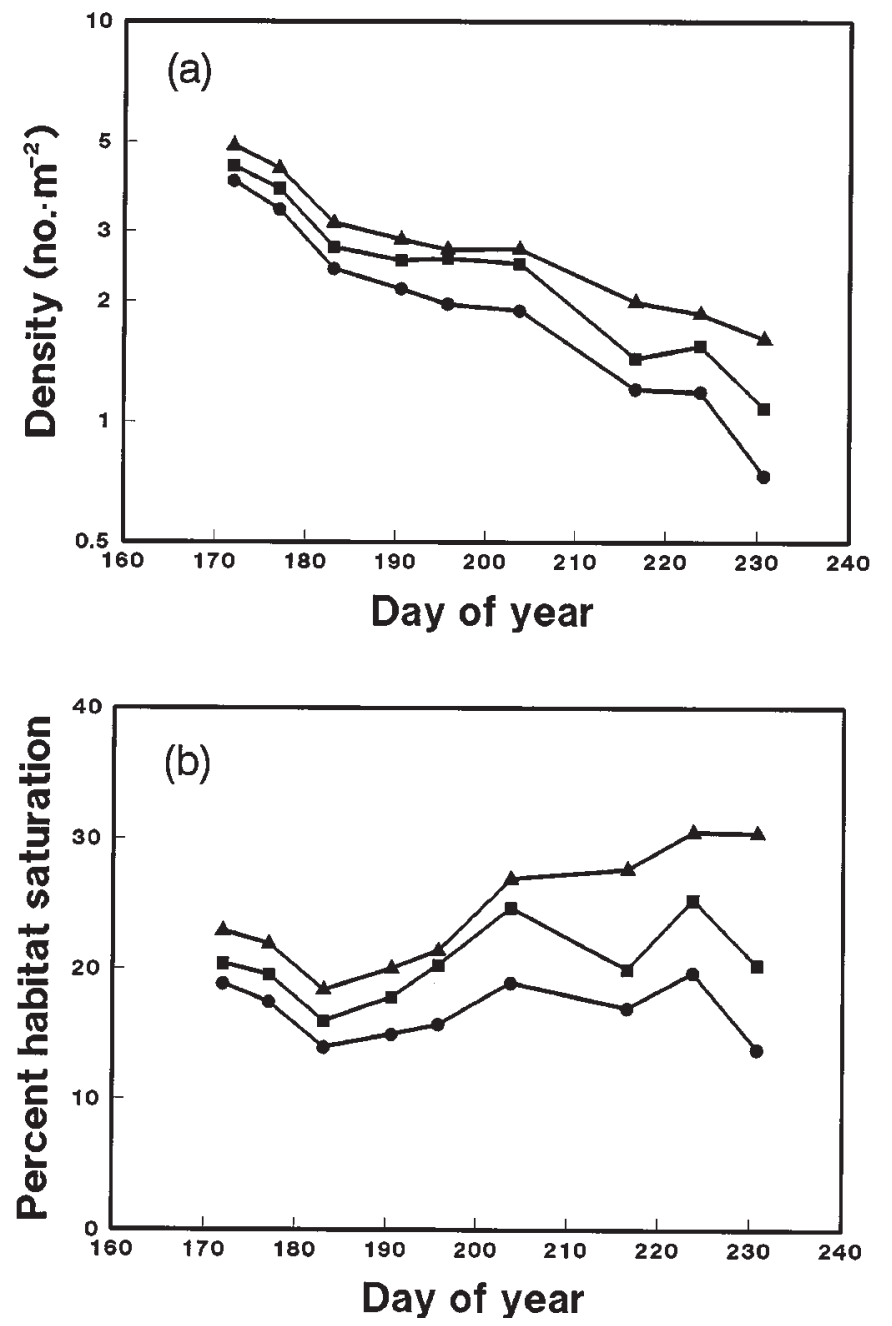

Fig. 3. Average effective density $(\bullet, \bigcirc)$ and PHS $(\boldsymbol{\Lambda}, \triangle)$ of juvenile Atlantic salmon at three spatial scales in 1995 (i.e., Fig. 2; open symbols) and from electrofishing data of Catamaran Brook in 1991-96 at four different spatial scales (closed symbols).

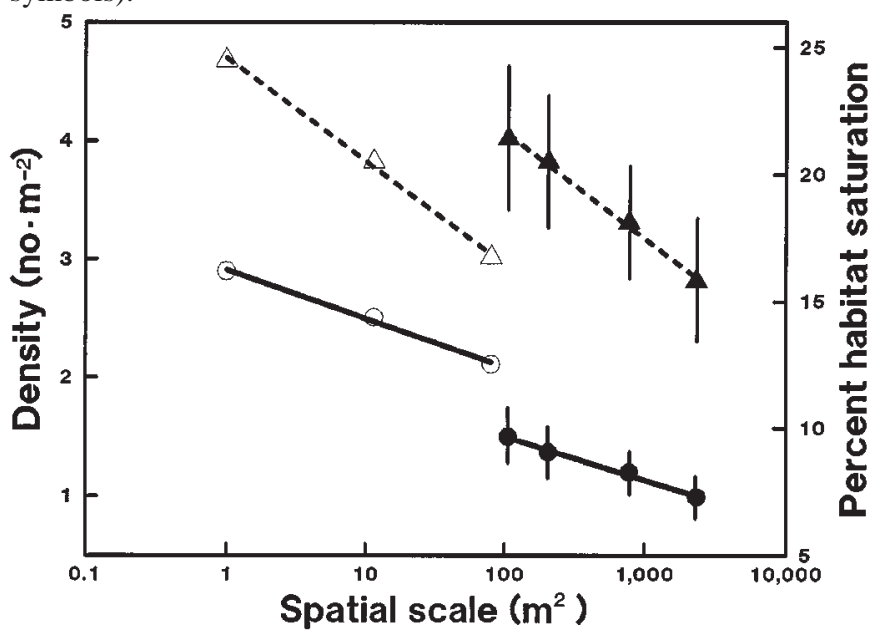


density is most commonly estimated by electrofishing sites of about $100 \mathrm{~m}^{2}$, the effective abundance that salmonids actually experience will often be underestimated. Population abundance will continue to be measured at a variety of spatial scales, so it would be useful to derive a general version of Fig. 3 to facilitate comparisons of data measured at a variety of spatial scales. In the absence of a general relationship between spatial scale and effective population abundance, spatial scale should be included as a covariate in any comparative analyses of salmonid abundance. For example, Grant and Kramer (1990) used PHS to predict the occurrence of density dependent population response. Presumably, this relationship would be even stronger if some of the noise in the PHS data was removed by adding spatial scale as a covariate.

\section{Food, space, and salmonid abundance}

Density dependent growth, mortality, and emigration have been widely reported in stream salmonid populations (Grant and Kramer 1990), indicating that competition is often intense. Because of the occurrence of feeding territories, food and (or) space have long been implicated as the causes of these density dependent responses (Chapman 1966; Allen 1969). But, how food abundance and territory size interact to affect density has not been clearly or quantitatively described. We can imagine four possible scenarios.

The food hypothesis predicts that salmonid abundance will be directly proportional to food abundance (i.e., a slope of 1.0). Hence, a doubling or halving of food abundance would cause a doubling or halving of salmonid abundance (e.g., PHS or biomass). The space hypothesis assumes that minimum territory size is inflexible and predicts a maximum population density (e.g., Allen 1969). The space-equals-food hypothesis assumes that population density is set by both food abundance and territory size. In this scenario, fish vary the size of their territory to maintain a constant supply of food on their territory, so that territory size is just the proximate mechanism for achieving the food hypothesis (e.g., McFadden 1969; Marschall and Crowder 1995). Hence, territory area is predicted to be inversely proportional to food abundance (i.e., a slope of -1.0), and salmonid abundance is predicted to be directly proportional to food abundance (i.e., a slope of 1.0). The food-and-space hypothesis also assumes that both food abundance and territory size affect salmonid abundance. While food abundance has an inverse effect on territory size, which in turn affects population density, no particular assumptions are made about the quantitative relationship between food abundance and territory size (e.g., Chapman 1966).

To test among the four scenarios, we searched the literature for papers that manipulated or measured food abundance while monitoring either territory size or the abundance of salmonids. We used PHS as our measure of abundance whenever possible; otherwise we used biomass or population density (the latter only when fish size did not change within a study). Thus, all measures of abundance were corrected for fish size. Measures of food abundance varied in quality; in decreasing order of quality they included average daily ration in experimental studies, the abundance of drift, or the biomass of benthic invertebrates.
For each study, we calculated mean territory size, food abundance and salmonid abundance and then expressed any changes in these variables as multiples of the mean.

Only two studies (Slaney and Northcote 1974; Dill et al. 1981) measured territory size while presenting food in a manner that simulates natural drift (for a review, see Grant and Noakes 1987). Territory size varied inversely with food abundance (Fig. 4a). Therefore, we can reject the space hypothesis, which assumes territory size is inflexible. We can also reject the space-equals-food hypothesis because territory size changed much less than one would expect if fish were maintaining a constant supply of food on their territories (Fig. 4a); the observed slope was significantly shallower than the predicted slope of -1.0 , assuming that food abundance is directly proportional to territory area. If food abundance is directly proportional to territory diameter rather than territory area (see Grant and Noakes 1987), then the difference between the slopes is even greater.

That territory size changes inversely with increases in food abundance is consistent with models of optimal territory size (Schoener 1983). It was surprising, however, how little territory size actually changed. Salmonids typically occupy contiguous territories and may not be "free" to choose the size of their territory. Salmonid territories may be compressed below their non-contiguous optimum by the pressure exerted by their territorial neighbours (Hixon 1980; Grant 1997).

We found only three studies that manipulated food abundance and measured the equilibrium abundance of salmonids. We were initially very cautious about using observational data because of the potential confounding effects of top-down control of food abundance (e.g., Bowlby and Roff 1986). Stream fertilization studies were categorized as observational because both food and salmonid abundance were dependent variables. Because the two types of data gave similar results (ANCOVA, $P=0.97$ ), however, we combined both into one analysis. Salmonid abundance increased significantly with food abundance, but the slope of the relationship was significantly less than 1.0 (Fig. 4b). The relationship changed little when the single low point in Fig. $4 b$ was deleted from the analysis (e.g., slope $=0.51 \pm$ $0.22, r=0.77, P<0.001)$. Therefore, we can reject the food hypothesis.

To test the food-and-space hypothesis, we overlaid the inverse of the territory area versus food abundance regression (Fig. $4 a$ ) on top of the data in Fig. 4b. For example, a doubling of food causes territories to shrink to 0.76 of their initial size, predicting an increase in salmonid abundance to 1.32 times its initial value. Changes in salmonid abundance were almost perfectly predicted by the inverse of the territory size versus food abundance regression (Fig. 4b). These data support the food-and-space hypothesis and suggest that changes in food abundance affect salmonid abundance, but only after passing through the "filter" of territory size.

We believe Fig. $4 b$ has important management implications. First, both regressions can be used to predict the response of salmonid populations to changes in food abundance. Second, these data would seem to suggest that increasing the productivity of a stream will have relatively little effect on salmonid abundance. For example, doubling the productivity of a stream would only increase juvenile 
Fig. 4. (a) Influence of changes in food abundance (multiples of the mean) on territory size (multiples of the mean) $(\mathbf{=}$ experiment 2, Slaney and Northcote 1974; $\mathbf{\Delta}$ = field data from Dill et al. 1981; $\mathbf{\square}=$ laboratory data from Dill et al. 1981). The dashed line is the least squares regression: $\log _{10}$ territory size $( \pm 95 \% \mathrm{CL})=0.0108( \pm 0.0490)-0.434( \pm 0.151) \log _{10}$ food abundance $(r=-0.93, n=9, P<0.001)$. The solid line is the predicted territory size if fish defend a constant amount of food, assuming food abundance is directly proportional to territory area. $(b)$ Influence of changes in food abundance (multiples of the mean) on salmonid abundance (multiples of the mean) $(-$ experimental studies: Slaney and Northcote 1974; Mesick 1988; Keeley 1998) ( $\bigcirc=$ observational data: Ellis and Gowing 1957; Warren et al. 1964; Murphy et al. 1981; Slaney and Ward 1993; Slaney et al. 1994; Toth et al. 1996; Toth et al. 1997). The dashed line is the least squares regression: $\log _{10}$ salmonid abundance $( \pm 95 \% \mathrm{CL})=0.487( \pm 0.149) \log _{10}$ food abundance $-0.0281( \pm 0.0739)(r=0.85, n=20, P<0.0001)$. The solid line is the one-to-one line and the dotted line is the inverse of the territory size regression in Fig. $4 a$ (i.e., $\log _{10}$ salmonid abundance $=0.434 \log _{10}$ food abundance -0.0108 ).
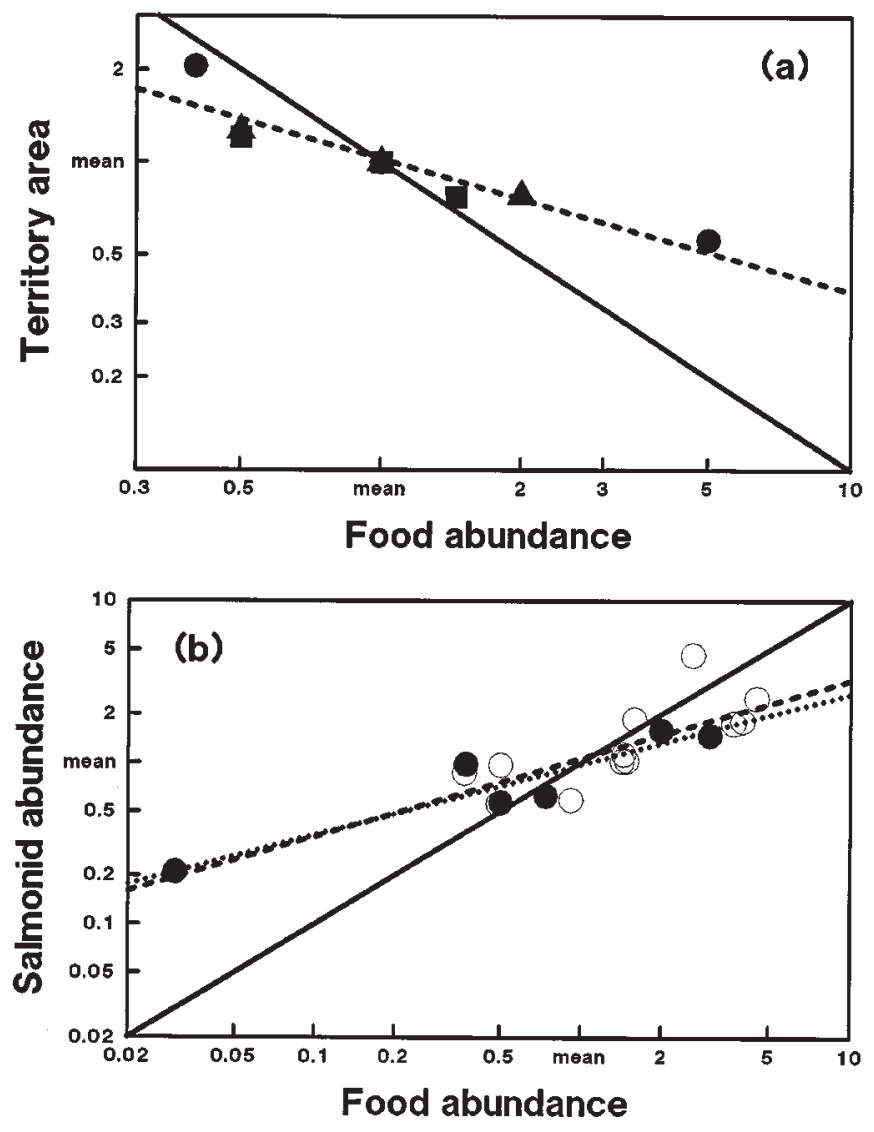

abundance by 1.32 times, whereas doubling the amount of juvenile habitat, perhaps by removing an unnatural barrier to upstream migration, would presumably double juvenile abundance. While the relationships in Fig. 4 are strong, the data are limited and of variable quality. Hence, we encourage future studies to quantify the relationship between food and salmonid abundance more rigorously in order to test these ideas further.
Fig. 5. Percent change in salmonid abundance/percent change in food abundance, for each of 10 studies in Fig. $4 b$, decreased with increasing PHS $(r=-0.62, n=10, P=0.054)$. For each study, PHS was calculated for the lower of two treatments or the mean of three treatments. $\bigcirc$ represent stream fertilization studies.

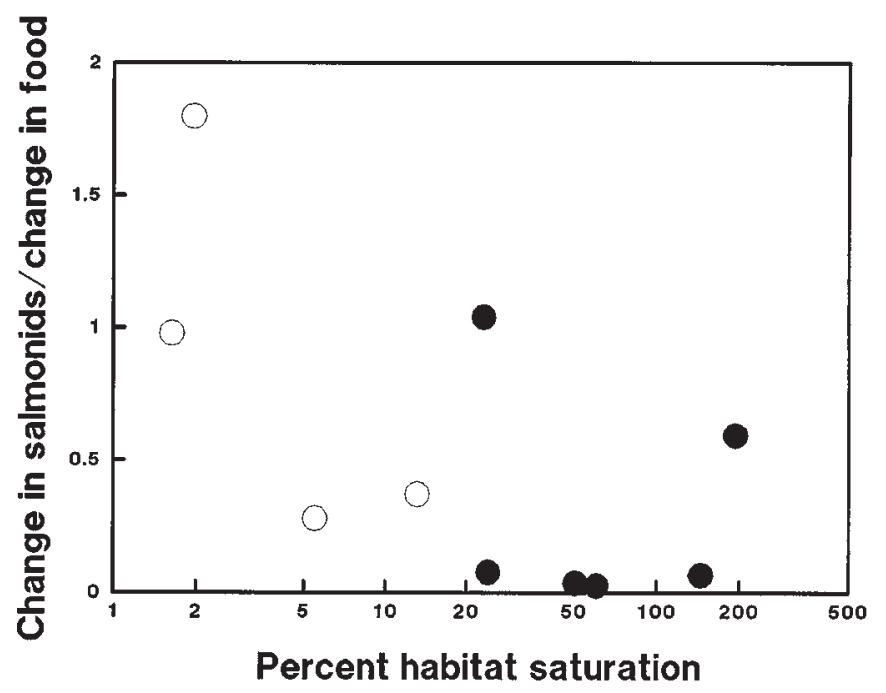

The prospects for stream fertilization are not quite so bleak as depicted in Fig. 4, because the response of salmonids to changes in food abundance also seem to depend on habitat saturation (Fig. 5). The fertilization of four streams increased the abundance of benthic invertebrates by an impressive average of 219\% (Slaney and Ward 1993; Slaney et al. 1994; Toth et al. 1996, 1997). The two streams with the greatest response in salmonid abundance had the lowest initial PHS values of 1.7 and 2\% (Toth et al. 1996, 1997). These data suggest that stream fertilization will only be useful in nutrient-poor streams with low initial salmonid abundance. Most of the increase in salmonid abundance resulting from fertilization was caused by an increase in growth rate rather than an increase in population density. Increased growth rate can be beneficial for fisheries managers if it increases overwinter survival of juveniles (e.g., Hunt 1969; Holtby 1988) or reduces mean smolt age (Hutchings and Jones 1998), and hence, increases smolt production (e.g., Slaney and Ward 1993). Unfortunately, increasing juvenile growth rate can also be detrimental by causing a higher proportion of sexually mature male parr or grilse in Atlantic salmon (Hutchings and Jones 1998; Marschall et al. 1998; Metcalfe 1998).

If the food-and-space hypothesis is correct, it suggests that territory size is the proximate factor that limits salmonid abundance. Hence, any environmental factor that reduces territory size should increase population density. Kalleberg (1958) increased the visual isolation of salmon parr, causing territory size to decrease by $51 \%$, presumably because of an increase in the costs of territory defence (see Eason and Stamps 1992). An experimental test of this hypothesis is needed. When Kalleberg increased current velocity from 18 to $29 \mathrm{~cm} \cdot \mathrm{s}^{-1}$, population density increased by $12 \%$, also presumably because of an increase in the costs of territory defence. Of the two factors, visual isolation had a greater effect on salmonid abundance and would seem to be easier 
to manipulate in the field. Neither manipulation is recommended, however, without first determining their effects on growth rate.

\section{Self-thinning and salmonid abundance}

What determines the abundance of a cohort is a separate but related issue to those of the previous section. Metabolic rate across species typically increases as $M^{0.75}$ (Peters 1983). If energy availability does not change with body size, then the "energetic equivalence hypothesis" (Bohlin et al. 1994) predicts that the density of species should scale to $M^{-0.75}$. Across species correlations between density and body mass are often consistent with the predicted slope of -0.75 (Peters and Wassenberg 1983; Nee et al. 1991).

Because of within population variation in body size, we might expect to see the same inverse relation between density and body mass within cohorts of juvenile salmonids. If such declines in density are caused by competition as the individuals within the cohort grow, then the process can be called self-thinning (Lonsdale 1990). In salmonid populations, food consumption and metabolic rate scale to body mass with an average exponent of 0.73 and 0.87 , respectively (Steingrímsson and Grant 1999). Thus, the energetic equivalence hypothesis predicts self-thinning slopes of -0.73 or -0.87 for salmonid fishes.

Competition for space could also provide a mechanism for self-thinning. In an interspecific analysis, territory size increased as $M^{0.86}$ (Grant and Kramer 1990). Subsequent studies have shown that allometric territory size relationships differ between species or studies with slopes that vary between 0.82 and 1.12 (Keeley and Grant 1995; Keeley and McPhail 1998). If territory size limits population density directly (e.g., Elliott 1990) or simply predicts spatial requirements of both territorial and non-territorial fish, then the space hypothesis predicts a self-thinning line with a slope between -0.82 and -1.12 .

Distinguishing between the space and energetic equivalence hypotheses, which are not necessarily mutually exclusive, will be difficult given the similarity of their predictions. For example, seven of the nine tests of these hypotheses were consistent with the predictions of both (Table 1). Only Elliott (1993) rejected the space hypothesis, whereas only Steingrímsson and Grant (1999) rejected the energetic equivalence hypothesis.

In reality, the two hypotheses may be more different than they first appear because of different underlying assumptions. Existing tests of the energetic equivalence hypothesis have assumed a constant food supply over time and body sizes (Begon et al. 1986; Bohlin et al. 1994). In contrast, the space hypothesis assumes that changes in food abundance are incorporated into the allometric, territory-size relationship. Juvenile Atlantic salmon are size selective foragers so that prey size increases with body size (Keeley and Grant 1997). The percentage of organisms in the drift that are of an edible size was about $90 \%$ for salmon less than $2 \mathrm{~g}$, but decreased rapidly with increasing body mass (Fig. 6). This decline in the number of prey available with increasing body size is only partly compensated by larger fish eating larger prey. Because the prey available in Catamaran Brook are small (Keeley and Grant 1997), the biomass of prey avail-
Fig. 6. Percentage of the organisms in the drift that are of an edible size in relation to body mass for juvenile Atlantic salmon in Catamaran Brook (Percent $=95.06-7.00 \log _{10}$ Mass -18.08 $\left.\left[\log _{10} \text { Mass }\right]^{2}\right)$. Each datum is the predicted value for each of 46 fish based on allometric relationships of minimum and maximum prey length and the length distribution of organisms captured in drift nets in Catamaran Brook (see Keeley and Grant 1997).

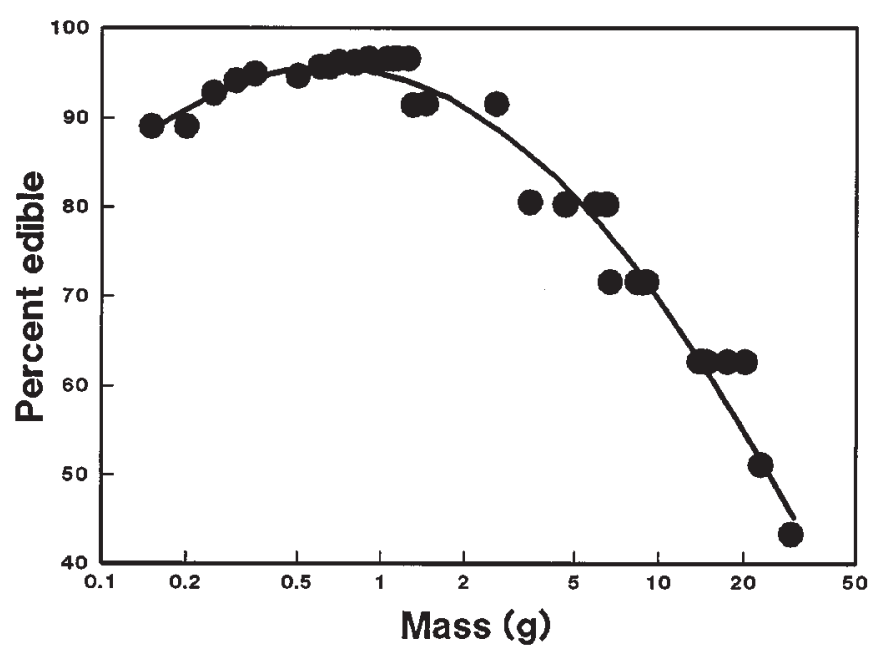

able to Atlantic salmon decreases with increasing body size. Seasonal changes in the drift pose an even bigger challenge to the assumption of constant food availability. The abundance of drift in streams often peaks in the late spring or early summer and declines over the growing season (O'Hop and Wallace 1983; Allan 1987; Keeley and Grant 1997). The energetic equivalence hypothesis can be modified to incorporate linear changes in food abundance. If metabolic rate scales as $M^{b}$ and food abundance scales as $M^{a}$, then the modified self-thinning slope is $M^{-b+a}$ (see Begon et al. 1986; Bohlin et al. 1994). Once the energetic equivalence hypothesis is modified to incorporate changes in food abundance with body mass, the two hypotheses may make quite different predictions.

Steingrímsson and Grant (1999) took advantage of seasonal changes in food abundance to test the predictions of the two hypotheses. The abundance of drift in Catamaran Brook declined by an average of $94 \%$ over the growing season, from $0.34 \mathrm{mg}$ dry weight per 20-min drift sample in mid June to $0.021 \mathrm{mg}$ in mid August. Hence, food for young-of-the-year salmon was proportional to $M^{-2.21}$. The predicted self-thinning slope of the corrected energetic equivalence hypothesis was -3.08 (i.e., $-\beta+\alpha=-0.87-$ $2.21=-3.08)$. In contrast, the space hypothesis, specifically for Atlantic salmon in Catamaran Brook, predicted a self-thinning slope of -1.12 (Keeley and Grant 1995). The observed self-thinning slope of -1.16 rejected both the uncorrected and corrected predictions of the energetic equivalence hypothesis, but supported the space hypothesis (Table 1).

Steingrímsson and Grant's (1999) analysis does not mean that self-thinning in Catamaran Brook is not affected by food density. Juvenile salmon in Catamaran Brook increase their territories as if they are trying to maintain a maximum daily ration of food flowing over their territory (Keeley and Grant 1995; also see Keeley and McPhail 1998). How can 
Table 1. "Self-thinning" slopes for stream-dwelling salmonids.

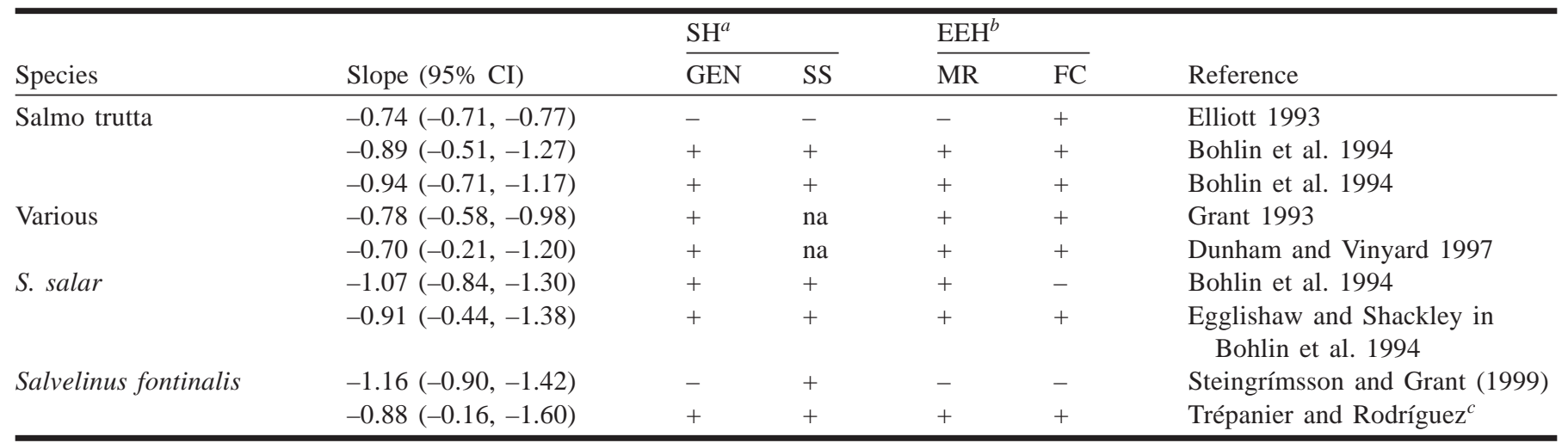

${ }^{a} \mathrm{SH}=$ space hypothesis. GEN $=$ predicted slope of -0.86 from an interspecific regression $($ Grant and Kramer 1990$)$. SS $=$ predicted slope of -0.82 and -0.99 for brown trout (Elliott 1990), -1.12 for Atlantic salmon (Keeley and Grant 1995), and -0.82 for brook trout $($ Grant and Kramer 1990). $+=$ predicted slope is within $95 \%$ CI of observed slope; $-=$ predicted slope outside of $95 \%$ CI of observed slope; na $=$ not applicable.

${ }^{b} \mathrm{EEH}=$ energetic equivalence hypothesis. $\mathrm{MR}=$ predicted slope of -0.87 based on the allometry of metabolic rate; FC $=$ predicted slope of -0.73 based on the allometry of food consumption (Steingrímsson and Grant 1999).

${ }^{c}$ S. Trépanier and M. Rodríguez, unpublished data. Département de biologie et des sciences de la santé, Université du Québec à Rimouski, CP 3300, Rimouski, Québec, Canada G5L 3A1.

they do this given the $94 \%$ decline in drift over the season? As the parr grow and increase the size of their territory, they also move to faster, deeper water. All three factors increase the number of potential prey that fish encounter over their territories (see Hughes and Dill 1990). These data suggest that self-thinning slopes will be steeper (i.e., more negative) in shallow, low-velocity habitats that experience a greater seasonal decline in drift. Steingrímsson and Grant (1999) observed just such a correlation, presumably because fish leave these sites as they grow larger.

The concept of self-thinning will always be more complicated to apply to mobile animals than to sedentary plants. First, it is difficult to know whether animals are experiencing food- or space-related competition at all. There is no easy way of distinguishing between cohorts that are truly self-thinning and those experiencing density-independent growth and mortality (see Armstrong 1997; Steingrímsson and Grant 1999). Ideally, a density-body mass relation should only be called self-thinning if density dependent competition is occurring in that population. Some of the variation in the "self-thinning" slopes reported by Bohlin et al. (1994) and Dunham and Vinyard (1997) likely result from including populations that are not experiencing density dependent competition. Given the difficulty in documenting the occurrence of density dependence, a simple rule-of-thumb might be to reserve the term self-thinning for cases when PHS, preferably effective PHS measured at a small spatial scale, is greater than or equal to $27 \%$, the abundance when density dependent competition is apparent (see Grant and Kramer 1990).

Second, the general self-thinning slope predicted by the energetic equivalence hypothesis may not be broadly applicable because of the failure of the assumption of constant food availability across body sizes. Powerful tests of the energetic equivalence hypothesis will, therefore, require monitoring size-dependent changes in food abundance for each study. Third, size-dependent changes in habitat preference will affect the self-thinning slope in different habitat types (Armstrong 1997; Steingrímsson and Grant 1999). Rather than being a shortcoming, Trépanier's (1997) study suggests self-thinning parameters can be used to determine habitat suitability. The allometry of space use will incorporate much of this variation in size-dependent changes in food abundance or habitat use. The generality of the space hypothesis, however, will depend on whether allometric territory size regressions can be broadly applied for a species or have to be described for each specific population under study. The usefulness of the self-thinning concept for salmonid ecologists will ultimately depend on its ability to generate novel, powerful predictions.

\section{Conclusions}

We believe a small-scale approach can provide new insights into the ecology of stream-dwelling salmonids that will complement studies at larger spatial scales. Quantifying territory size appears to be a useful starting point for measuring the abundance of salmonids in streams. Because of spatial heterogeneity, our perception of salmonid abundance from the organism's point of view increases as the spatial scale at which the abundance is measured decreases. Information about territory size is also useful in predicting changes in the abundance of cohorts over time and the response of populations to changes in food abundance. Future research should test the hypothesis that density dependent processes will likely be easier to detect as the spatial scale of the study decreases.

\section{Acknowledgments}

We are grateful to Richard Degraaf, Robert Lewis, and Keith Jensen of the Northeastern Forest Experiment Station of the USDA Forest Service for sponsoring the workshop on "Integrating across scales: predicting patterns of change in Atlantic salmon". Our research was financially supported by grants from the Natural Sciences and Engineering Research Council of Canada (NSERC) and the Faculty Research Development Program of Concordia University to J.W.A.G., from Fisheries and Oceans Canada (Science Branch, Moncton), the Miramichi Salmon Association, the Atlantic 
Salmon Federation, and the New Brunswick Environmental Trust Fund to R.A.C., from NSERC to Don McPhail, and from the British Columbia Ministry of Environment, Lands and Parks to E.R.K. We thank Peter Hardie and Ivan Benwell for collecting most of the long-term data at Catamaran Brook. Comments by John Armstrong and an anonymous referee greatly improved the manuscript.

\section{References}

Allan, J.D. 1987. Macroinvertebrate drift in a Rocky Mountain stream. Hydrobiologia, 144: 261-268.

Allen, K.R. 1969. Limitations on production in salmonid populations in streams. In Symposium on salmon and trout in streams. Edited by T.G. Northcote. University of British Columbia, Vancouver, B.C. pp. 3-18.

Armstrong, J.D. 1997. Self-thinning in juvenile sea trout and other salmonid fishes revisited. J. Anim. Ecol. 66: 519-526.

Armstrong, J.D., Grant, J.W.A., Forsgren, H.L., Fausch, K.D., DeGraaf, R.M., Fleming, I.A., Prowse, T.D., and Schlosser, I.J. 1998. The application of science to the management of Atlantic salmon (Salmo salar): integration across scales. Can. J. Fish. Aquat. Sci. 55 (Suppl. 1): 303-311.

Begon, M., Firbank, L., and Wall, R. 1986. Is there a self-thinning rule for animal populations? Oikos, 46: 122-124.

Begon, M., Harper, J.L., and Townsend, C.R. 1996. Ecology. 3rd edition. Blackwell, Oxford.

Bohlin, T., Dellefors, C., Faremo, U., and Johlander, A. 1994. The energetic equivalence hypothesis and the relation between population density and body size in stream-living salmonids. Am. Nat. 143: 478-493.

Bowlby, J.N., and Roff, J.C. 1986. Trophic structure in southern Ontario streams. Ecology, 67: 1670-1679.

Chapman, D.W. 1966. Food and space as regulators of salmonid populations in streams. Am. Nat. 100: 345-357.

Cunjak, R.A. 1996. Winter habitat of selected stream fishes and potential impacts from land-use activity. Can. J. Fish. Aquat. Sci. 53(Suppl. 1): 267-282.

Cunjak, R.A., Caissie, D., El-Jabi, N., Hardie, P., Conlon, J.H., Pollock, T.L., Giberson, D.J., and Komadina-Douthwright, S. 1993. The Catamaran Brook (New Brunswick) Habitat Research Project: biology, physical and chemical conditions (1990-1992). Can. Tech. Rep. Fish. Aquat. Sci. No. 1914.

Cunjak, R.A., and Therrien, J. 1996. Modeling Atlantic salmon population dynamics in a small stream. In Ecohydraulics 2000. Proceedings of the 2nd International Symposium on Habitat Hydraulics. Edited by J. Leclerc, H. Capra, S. Valentin, A. Boudreault, and Y. Côté. INRS-Eau, Québec. pp. B477-486.

deGraaf, D.A., and Bain, L.H. 1986. Habitat use and preferences of juvenile Atlantic salmon in two Newfoundland rivers. Trans. Am. Fish. Soc. 115: 671-681.

Dill, L.M., Ydenberg, R.C., and Fraser, A.H.G. 1981. Food abundance and territory size in juvenile coho salmon (Oncorhynchus kisutch). Can. J. Zool. 59: 1801-1809.

Dunham, J.B., and Vinyard, G.L. 1997. Relationships between body mass, population density, and the self-thinning rule in stream-living salmonids. Can. J. Fish. Aquat. Sci. 54: 1025-1030.

Eason, P.K., and Stamps, J.A. 1992. The effect of visibility on territory size and shape. Behav. Ecol. 3: 166-172.

Elliott, J.M. 1984. Numerical changes and population regulation in young migratory trout Salmo trutta in a Lake District stream, 1966-83. J. Anim. Ecol. 53: 327-350.
Elliott, J.M. 1990. Mechanisms responsible for population regulation in young migratory trout, Salmo trutta. III. The role of territorial behaviour. J. Anim. Ecol. 59: 803-818.

Elliott, J.M. 1993. The self-thinning rule applied to juvenile sea-trout, Salmo trutta. J. Anim. Ecol. 62: 371-379.

Ellis, R.J., and Gowing, H. 1957. Relationships between food supply and condition of wild brown trout, Salmo trutta Linnaeus, in a Michigan stream. Limnol. Oceanogr. 11: 299-308.

Fausch, K.D. 1988. Tests of competition between native and introduced salmonids in streams: what have we learned? Can. J. Fish. Aquat. Sci. 45: 2238-2246.

Folt, C.L., Nislow, K.H., and Power, M.E. 1998. Implications of temporal and spatial scale for Atlantic salmon (Salmo salar) research. Can. J. Fish. Aquat. Sci. 55(Suppl. 1): 9-21.

Fretwell, S.D, and Lucas, H.J. Jr. 1970. On territorial behavior and other factors influencing habitat distribution in birds. Acta Biotheor. 19: 16-36.

Grant, J.W.A. 1990. Aggressiveness and the foraging behaviour of young-of-the-year brook charr (Salvelinus fontinalis). Can. J. Fish. Aquat. Sci. 47: 915-920.

Grant, J.W.A. 1993. Self-thinning in stream-dwelling salmonids. Can. Spec. Publ. Fish. Aquat. Sci. 118. pp. 99-102.

Grant, J.W.A. 1997. Territoriality. In Behavioural ecology of teleost fishes. Edited by J-G.J. Godin. Oxford University Press, Oxford. pp. 81-103.

Grant, J.W.A., and Kramer, D.L. 1990. Territory size as a predictor of the upper limit to population density of juvenile salmonids in streams. Can. J. Fish. Aquat. Sci. 47: 1724-1737.

Grant, J.W.A., and Noakes, D.L.G. 1987. A simple model of optimal territory size for drift-feeding fish. Can. J. Zool. 65: 270-276.

Grant, J.W.A., Chapman, C.A., and Richardson, K.S. 1992. Defended versus undefended home range size of carnivores, ungulates and primates. Behav. Ecol. Sociobiol. 31: 149-161.

Gross, M.R. 1996. Alternative reproductive strategies and tactics: diversity within sexes.Trends Ecol. Evol. 11: 92-98.

Hixon, M.A. 1980. Food production and competitor density as the determinants of feeding territory size. Am. Nat. 115: 510-530.

Holtby, L.B. 1988. Effects of logging on stream temperatures in Carnation Creek, British Columbia, and associated impacts on coho salmon (Oncorhynchus kisutch). Can. J. Fish. Aquat. Sci. 45: 502-515.

Hughes, N.F., and Dill, L.M. 1990. Position choice by drift-feeding salmonids: model and test for Arctic grayling (Thymallus arcticus) in subarctic mountain streams, interior Alaska. Can. J. Fish. Aquat. Sci. 47: 2039-2048.

Hunt, R.L. 1969. Overwinter survival of wild fingerling brook trout in Lawrence Creek, Wisconsin. J. Fish. Res. Board Can. 26: $1473-1483$.

Hutchings, J.A., and Jones, M.E.B. 1998. Life history variation within and among populations of Atlantic salmon, Salmo salar. Can. J. Fish. Aquat. Sci. 55(Suppl. 1): 22-47.

Imhof, J.G., Fitzgibbon, J., and Annable, W.K. 1996. A hierarchical evaluation system for characterizing watershed ecosystems for fish habitat. Can. J. Fish. Aquat. Sci. 53(Suppl. 1): 312-326.

Jarman, P.J. 1974. The social organization of antelope in relation to their ecology. Behaviour, 48: 215-267.

Kalleberg, H. 1958. Observations in a stream tank of territoriality and competition in juvenile salmon and trout (Salmo salar L. and S. trutta L.). Inst. Freshwater Res. Drottningholm Rep. 39: 55-98.

Keeley, E.R. 1998. Behavioural and demographic responses to food and space competition by juvenile steelhead trout 
(Oncorhynchus mykiss). Ph.D. thesis, The University of British Columbia, Vancouver, B.C.

Keeley, E.R., and Grant, J.W.A. 1995. Allometric and environmental correlates of territory size in juvenile Atlantic salmon (Salmo salar). Can. J. Fish. Aquat. Sci. 52: 186-196.

Keeley, E.R., and Grant, J.W.A. 1997. Allometry of diet selectivity in juvenile Atlantic salmon (Salmo salar). Can. J. Fish. Aquat. Sci. 54: 1894-1902.

Keeley, E.R., and J.D. McPhail. 1998. Food abundance, intruder pressure, and body size as determinants of territory size in juvenile steelhead trout (Oncorhynchus mykiss). Behaviour, 135: 65-82.

Kennedy, G.J.A., and Strange, C.D. 1986. The effects of intra- and inter-specific competition on the survival and growth of stocked juvenile Atlantic salmon, Salmo salar L., in an upland stream. J. Fish. Biol. 28: 479-489.

Krebs, C.J. 1989. Ecological methodology. Harper and Row, New York, N.Y.

Krebs, C.J. 1994. Ecology. 4th ed. Harper Collins, New York.

Lewis, C.A., Lester, N.P., Bradshaw, A.D., Fitzgibbon, J.E., Fuller, K., Hakanson, L, and Richards, C. 1996. Considerations of scale in habitat conservation and restoration. Can. J. Fish. Aquat. Sci. 53(Suppl. 1): 440-445.

Lewontin, R.C., and Levins, R. 1989. On the characterization of density and resource availability. Am. Nat. 134: 513-524.

Lonsdale, W.M. 1990. The self-thinning rule: dead or alive? Ecology, 71: 1373-1388.

Marschall, E.A., and Crowder, L.B. 1995. Density-dependent survival as a function of size in juvenile salmonids in streams. Can. J. Fish. Aquat. Sci. 52: 136-140.

Marschall, E.A., Quinn, T.P., Roff, D.A., Hutchings, J.A., Metcalfe, N.B., Bakke, T.A., Saunders, R.L., and Poff, N.L. 1998. A framework for understanding Atlantic salmon (Salmo salar) life history. Can. J. Fish. Aquat. Sci. 55(Suppl. 1): 48-58.

McFadden, J.T. 1969. Dynamics and regulation of salmonid populations in streams. In Symposium on salmon and trout in streams. Edited by T.G. Northcote. University of British Columbia, Vancouver, B.C. pp. 313-329.

Mesick, C.F. 1988. Effects of food and cover on numbers of Apache and brown trout establishing residency in artificial stream channels. Trans. Am. Fish. Soc. 117: 421-431.

Metcalfe, N.B. 1998. The interaction between behaviour and physiology in determining life history patterns in Atlantic salmon (Salmo salar). Can. J. Fish. Aquat. Sci. 55(Suppl. 1): 93-103.

Morantz, D.L., Sweeney, R.K., Shirvell, C.S., and Longard, D.A. 1987. Selection of microhabitat in summer by juvenile Atlantic salmon (Salmo salar). Can. J. Fish. Aquat. Sci. 44: 120-129.

Murphy, M.L., Hawkins, C.P., and Anderson, N.H. 1981. Effects of canopy modification and accumulated sediment on stream communities. Trans. Am. Fish. Soc. 110: 469-478.

Nee, S., Read, A.F., Greenwood, J.D., and Harvey, P.H. 1991. The relationship between abundance and body size in British birds. Nature, 351: 312-313.

O'Hop, J., and Wallace, J.B. 1983. Invertebrate drift, discharge, and sediment relations in a southern Appalachian headwater stream. Hydrobiologia, 98: 71-98.

Peters, R.H. 1983. The ecological implications of body size. Cambridge University Press, Cambridge.

Peters, R.H., and Wassenberg, K. 1983. The effect of body size on animal abundance. Oecologia, 60: 89-96.

Puckett, K.J., and Dill, L.M. 1985. The energetics of feeding territoriality in juvenile coho salmon (Oncorhynchus kisutch). Behaviour, 92: 97-111.

Rabeni, C.F., and Sowa, S.P. 1996. Integrating biological realism into habitat restoration and conservation strategies for small streams. Can. J. Fish. Aquat. Sci. 53 (Suppl. 1): 252-259.

Randall, R.G. 1982. Emergence, population densities, and growth of salmon and trout fry in two New Brunswick streams. Can. J. Zool. 60: 2239-2244.

Ray, C., and Hastings, A. 1996. Density dependence: are we searching at the wrong spatial scale? J. Anim. Ecol. 65: $556-566$.

Scott, W.B., and Scott, M.G. 1988. Atlantic fishes of Canada. Can. Bull. Fish. Aquat. Sci. No. 219.

Schoener, T.W. 1983. Simple models of optimal feeding-territory size: a reconciliation. Am. Nat. 121: 608-629.

Slaney, P.A., and Northcote, T.G. 1974. Effects of prey abundance on density and territorial behavior of young rainbow trout (Salmo gairdneri) in laboratory stream channels. J. Fish. Res. Board Can. 31: 1201-1209.

Slaney, P.A., and Ward, B.R. 1993. Experimental fertilization of nutrient deficient streams in British Columbia. In Le développement du saumon atlantique au Québec: connaître les règles du jeu pour réussir. Edited by G. Shooner and S. Asselin. Colloque international de la Fédération québécoise pour le saumon atlantique, Québec. pp. 128-141.

Slaney, P., Ashley, K., Wightman, C., Ptolemy, R., and Zaldokas, D. 1994. Low-level fertilization as a habitat management option for nutrient deficient trout streams in British Columbia. In Proceedings of the 9th international trout stream habitat improvement workshop. Trout Unlimited Canada. pp. 1-23.

Smith, R.L. 1996. Ecology and field biology. 5th ed. Harper Collins, New York, N.Y.

Steingrímsson, S.Ó. 1996. The allometry of territory size and metabolic rate as predictors of self-thinning in young-of-the-year Atlantic salmon (Salmo salar). M.Sc. thesis, Concordia University, Montréal, Qué.

Steingrímsson, S.Ó., and Grant, J.W.A. 1999. Allometry of territory size and metabolic rate as predictors of self-thinning in young-of-the-year Atlantic salmon. J. Anim. Ecol. 68: 17-26.

Symons, P.E.K., and Heland, M. 1978. Stream habitats and behavioral interactions of underyearling and yearling Atlantic salmon (Salmo salar). J. Fish. Res. Board Can. 35: 175-183.

Titus, R.G. 1990. Territorial behavior and its role in population regulation of young brown trout (Salmo trutta): new perspectives. Ann. Zool. Fennici, 27: 119-130.

Toth, B., Ashley, K., Wilson, G., Koning, C.W., Slaney, P., and Land, R.W. 1996. Development of a premier river fishery: Big Silver Creek fertilization experiment, year two (1995) of low-level inorganic nutrient addition. Fisheries Project Report No. RD 56, Ministry of Environment, Lands and Parks, British Columbia.

Toth, B., Ashley, K., Wilson, G., Koning, C.W., Slaney, P., Rimmer, D., and Land, R. 1997. Development of a resident trout fishery on the Adam River through increased habitat productivity: year two (1995) of low-level inorganic nutrient addition. Fisheries Project Report No. RD 57, Ministry of Environment, Lands and Parks, British Columbia.

Trépanier, S. 1997. Relation d'auto-éclaircie et production chez les populations d'omble de fontaine, Salvelinus fontinalis, en sympatrie avec les juvéniles du saumon de l'atlantique, Salmo salar. M.Sc. thesis, Université du Québec à Trois-Rivières, Québec. 